\title{
Niels Stensen and the Discovery of the Parotid Duct
}

\author{
Niels Stensen y el Descubrimiento del Conducto Parotídeo
}

\author{
Goran Strkalj*
}

STRKALJ, G. Niels Stensen and the discovery of the parotid duct. Int. J. Morphol., 31(4):1491-1497, 2013.

SUMMARY: Niels Stensen was a renowned Danish scientist, theologian and Catholic bishop. Stensen's early career was devoted to anatomy and it is in this discipline that he made many important contributions. His method in anatomy was rooted in systematic observations based on meticulously executed dissections of human and animal cadavers, as well as experiments on animals. His first important discovery in the field of anatomy, which is the main focus of this paper, was the discovery of the parotid duct. The discovery brought Stensen recognition and fame but only after a controversy in which he was accused of plagiarism by his mentor Gerard Blaes. Although still in an early stage of his career Stensen dealt with the accusation masterfully, producing further research which confirmed him as the discoverer of the parotid duct.

KEY WORDS: Niels Stensen; History of anatomy; Parotid duct; Scientific discovery.

\section{INTRODUCTION}

The year 2013 marks the 375 th anniversary of the birth of the renowned Danish scholar Niels Stensen (Fig. 1). He is remembered for his contribution to science, theology and as a Catholic bishop who was beatified by Pope John Paul II in 1988. Stensen's remarkable scientific opus includes seminal contributions to anatomy and geology. In anatomy he made several important discoveries, described previously unknown structures and elucidated their function. Stensen was also an enigmatic figure with complex personality. Indeed, William Osler, after praising Stensen as a scientist and a theologian added that the Dane was "a strange figure, one of the strangest in our history" (Osler, 1913). Stensen's life was full of sharp contrasts and dramatic changes - in his career, his faith and his outlook at life. Although he was praised highly for his scientific achievements and was acquainted with the social and intellectual elite of the day, he lived a humble life. Stensen started his career as a physician and anatomist but later turned his research focus almost completely to geology. Later, he would leave natural sciences altogether, convert from Protestantism to Catholicism and become a theologian and, subsequently, a dedicated priest and bishop. While the spheres of his interest seemed to change, his insatiable thirst for knowledge and discovery both in the realm of natural phenomena and in spirituality remained dominant throughout his life. He lived an ascetic life and followed the high moral principles prescribed by his Christian faith,

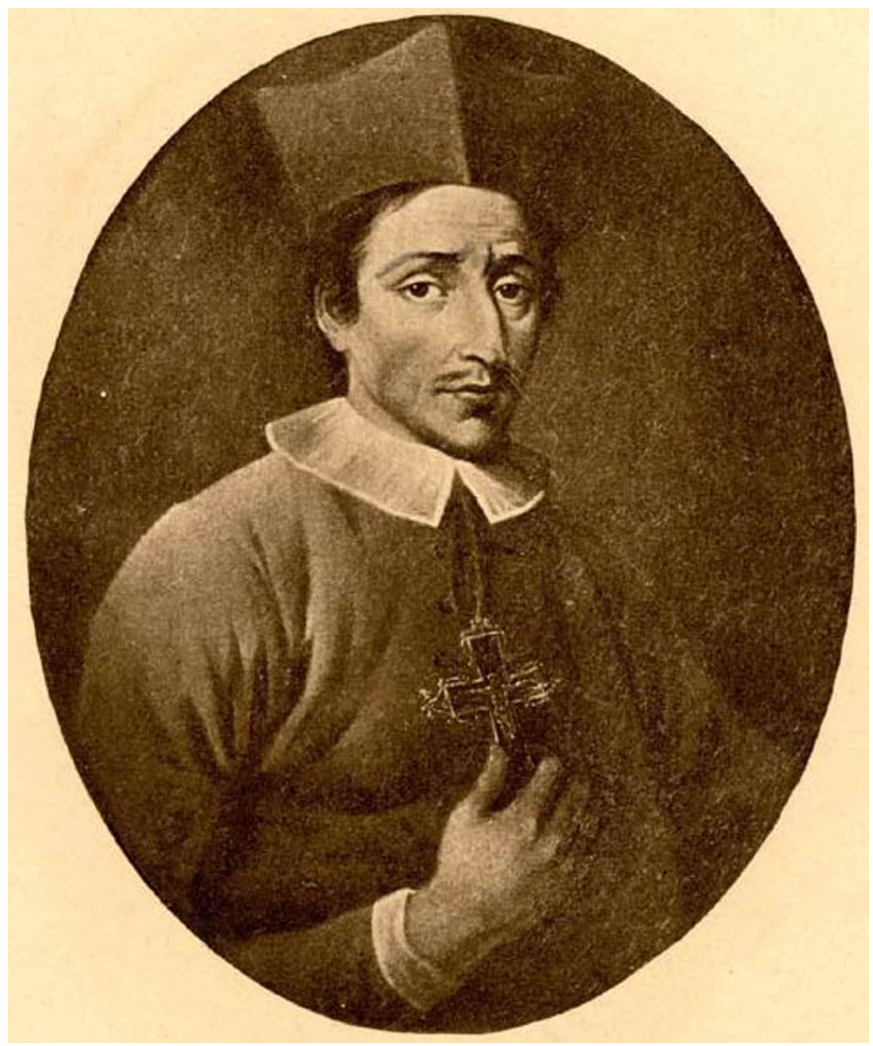

Fig. 1. Niels Stensen (1638-1686). 
provoking admiration of some but jealousy and even hatred in many more.

This paper provides an historical analysis of Stensen's discovery of the parotid duct - the accomplishment for which he is best known today. While this discovery and its implications can be comprehended only within the historical context and the idiosyncrasies of the seventeenth century science and society, it also bears some "universal" features of an anatomical discovery and an event that produced a significant advancement in the discipline of anatomy, which are pertinent to contemporary science. The present analysis relies on the recently published English translation of Stensen's collected scientific works, edited by Kardel \& Maquet (2013). This valuable resource is an updated version of the collection of Stensen's scientific papers that was first published in original languages by Vilhelm Maar (1910) (most of Stensen's works were published in Latin, as was the custom at the time, with only a few in French and Italian). The new collection also contains a translation into English of the classical biography of Stensen written, in German, by Gustav Scherz (1987).

\section{LIFE AND TIMES}

Niels Stensen (1638-1686) was born in Copenhagen as the first child of the goldsmith Sten (or Steen) Pedersen and his wife Anne Nielsdatter (Cutler, 2003; Kermit, 2003; Kardel \& Maquet). Steno's name has numerous alternative spellings. He was born Niels Stensen (sometimes spelled Steensen), but while studying medicine, mathematics and philosophy at the University of Copenhagen, following the custom of the day, he Latinised his name. His new academic name was Nicolai Stenonis. However, in various documents and correspondence, his name also appears as Nicolaus Stenonis, Nicolas Sténon (French version) and Niccolò Stenone (Italian). Today, his name, especially in the English speaking world, is often spelled as Nicolaus or Nicolas Steno (Kardel \& Maquet). This abbreviation of the surname might have been a result of misunderstanding, where Stenonis was taken to be the genitive case (Field \& Harrison, 1947).

At the University of Copenhagen Stensen studied under several renowned academics, including the anatomist Thomas Bartholin. However, mainly due to the prolonged war with Sweden and the exhausting siege of Copenhagen, the academic standards at the university were far from ideal. In 1660, without graduating, Stensen moved to the Dutch Republic via northern Germany where he visited several institutions. He spent several months in Amsterdam working under physician and anatomist Gerard Blaes, before moving to the University of Leiden where he completed his medical studies. At the same time, Stensen was deeply immersed in anatomy research. Years spent in the Dutch Republic were of great importance for Stensen's scientific development. The seventeenth century is known as the Golden Century of the Dutch Republic, as the country was experiencing unprecedented economic development, enjoyed high level of personal, religious and academic freedoms and enabled numerous intellectual leaders to produce significant advancements in philosophy, arts and natural sciences. Indeed, the University of Leiden had, at the time of Stensen, been established as one of Europe's leading universities and medical schools and provided a perfect setting for the advancement of a young, inquisitive scientist (Kidd \& Modlin, 1999). In Amsterdam and Leiden, Stensen got in contact not only with eminent medical and scientific figures such as Jan Swammerdam, Frederik Ruysch, Reinier de Graaf, Franciscus Sylvius, but also scholars from other fields, including the renowned philosopher Baruh Spinoza.

Stensen moved to France in 1664 and spent the next two years focusing on research and anatomy demonstrations. In Paris, where he stayed as a guest of the wealthy diplomat, writer, scientist and the patron of science Melchisédech Thévenot, Stensen and his displays at Theatrum Anatomicum (anatomical theatre) made a deep impression on the capital's leading academics. From France he moved to Italy. In Rome he met Pope Alexander VII and yet another scientific luminary, Marcello Malpighi. Most of his time in Italy, which were perhaps his happiest years, was spent in Florence at the court of Ferdinando II de'Medici, Duke of Tuscany. Ferdinando and his brother Leopoldo were devoted patrons of science and Stensen was given high level of freedom in his scientific pursuits. He used that freedom to gradually change his focus from anatomy to geology. Stensen's contribution to geology is remarkable as he made seminal contribution to stratigraphy (Stensen's three principles are still accepted today) and towards modern explanation of the formation of fossils. In Florence Stensen became a member of the Accademia del Cimento - Academy of Experiments, an eminent scientific association based on the model of science envisaged by Galileo. Stensen was in contact with a number of renowned members of the Academy including Francesco Redi, who, at the time of Stensen's arrival, carried out his famous experiments which tested the theory of spontaneous generation.

Florence was also the stage of the religious drama that was unfolding in Stensen's life. In 1667 he converted to Catholicism and was ordained a priest eight years later. With his ordination his focus in life changed and his active research in natural science diminished. His involvement in science from then on was only occasional and marginal, as he became 
dedicated to theology and his duties as a priest and later a bishop. He was to play a prominent role in the CounterReformation movement. In 1679 Stensen was consecrated titular bishop of Titiopolis and resumed his duties in the northern and western Germany, Denmark and Norway, traditionally Lutheran countries. While based in Hanover as a guest of Duke Johann Frederich, Stensen was in contact with another prominent intellectual, mathematician and philosopher, Gottfried Wilhelm von Leibniz. Leibniz, however, was disappointed with Stensen's lack of interest in science. Stensen carried out his duties diligently, but encountered resistance from both Protestant majority and Catholic minority who often could not follow his high standards of religious dedication.

Stensen lived an ascetic life, especially later in life when he was living on a bare minimum for subsistence. The ascetic way of life and constant pressures contributed toward the deterioration of his health and his demise in Germany when he was only 48 years old. Stensen's remains were sent to Florence upon the request of Ferdinando's son, Cosimo III de'Medici and buried in the Basilica of San Lorenzo.

\section{ANATOMY}

Stensen's early career was dedicated to anatomy. The choice of anatomy is not surprising as this discipline attracted many ambitious and talented young scholars. Indeed, at this time, anatomy (although the study of function rather than structure was becoming more prominent) was a cutting edge discipline in which many breakthrough discoveries were being constantly made, akin to today's research in genetics or molecular biology (Singer, 1957; Persaud, 1997). Anatomy also had a public appeal and recognition. Anatomical dissections were carried out not only for the sake of research and medical education, but were also public spectacles which could be attended by all those who could afford a ticket. Demonstrations in Theatrum Anatomicum, a place where dissections were carried out, were well attended in numerous cities across Europe (Schumacher, 2007).

The key to Stensen's success in anatomy and his high standing in the discipline was largely due to his approach. Several of Stensen's anatomical treatises include his views on approaches to studying anatomy in both methodology and more general outlook - what would now be termed philosophy of science. Two activities marked Stensen's approach to research in anatomy - dissections of both humans and animals (carried out by Stensen himself) and experiments on animals (Perrini et al., 2010).

Dissections of human cadavers, which were rare in
Antiquity and flourished only briefly in Hellenistic Alexandria (Von Staden, 1989; Strkalj \& Chorn, 2008), were revived by the late thirteen century Italian scholars (Singer; Kevorkian, 1959; Persaud, 1984). However, for a lengthy period of time, dissections were carried out only to confirm what was written in the classical medical texts. Even Mondino de' Liuzzi, the fourteenth century "restorer of anatomy" (Crivellato \& Ribatti, 2006) and the author of the first modern textbook, the Anothomia, relied on the authority of the classical authors. $\mathrm{He}$, as Charles Singer noted, was "dissecting to memorize their works, much as a student nowadays dissects to memorize his textbook, not to enlarge knowledge nor to make discoveries" (Singer). It was Andreas Vesalius who dramatically changed that practice and started to investigate the human body using dissection as his primary tool (O'Malley, 1964; Joffe, 2009). This enabled him to enlarge the knowledge of anatomy and correct many mistakes present in the classical works. In spite of strong resistance Vesalian approach prevailed and became a mark of modern anatomy.

Stensen adopted Vesalian approach to anatomy fully (Kardel\& Maquet). Rather than uncritically relying on a classical text originating in Antiquity, Stensen gained information about anatomical structures through meticulous dissections. While having a great respect for his predecessors from the past he noted "these [classical authors] ignited the light but we should take care that it continues to burn and over the course of time always more clearly shines" (Stensen in Kardel \& Maquet, 2013: 74). Stensen also criticised speculative elements in the anatomical research of his contemporaries. This even included the scholars who, with both their theoretical insights and practical engagement, gave significant contributions to the development of modern science. Stensen, for example, disapproved of René Descartes' anatomy when it was based on the approach that was deductive and speculative rather than based on dissections (which Descartes also performed) (Kardel \& Maquet). This approach seemed to have been behind some of the main ideas presented in the famous philosopher's posthumously published De Homine. At the same time, Stensen was strongly influenced by and very positive about Descartes philosophy and general method - he claimed that he disapproved of Descartes only when Descartes did not follow his own methodological dictum.

Thus, Stensen falsified Descartes' thesis that the pineal gland was the organ that connected the body and the soul (Kardel \&Maquet). Descartes believed that the pineal gland was positioned inside the ventricles of the brain and attached to them by a network of capillaries. The smallest particles from the blood vessels, Descartes speculated, filtered into the gland to be transformed into animal spirits and released into various areas in the ventricles. In the process, the gland would rather vigorously move and spin in different directions to 
facilitate the distribution of spirits. Stensen's careful dissection revealed the correct position of the gland and demonstrated that it was rather a fragile structure attached directly to the brain. He also established that the pineal gland tended to break easily when moved, therefore it was a structure that could not have produced motion as postulated by Descartes.

In a similar vein, Stensen criticised Thomas Willis (Kardel \& Maquet). While praising Willis highly for his description and drawings in Cerebri Anatome (which contained only minor mistakes) Stensen was critical of Willis's tendency to speculate. Interestingly, as Stanley Finger (1994) noted, "Willis recognized that his love for speculations was a fault, albeit one difficult to overcome".

Stensen was known as an outstanding dissector (Cutler; Kardel\& Maquet). In public perception, his abilities reached almost mythical proportions. In Paris, a physician who attended Stensen's dissection noted "He is constantly dissecting. He has patience that is inconceivable, and with practice he has acquired a technique above the ordinary. Neither a butterfly nor a fly escapes his skill. He would count the bones of a flea - if fleas have bones" (Cutler, 2003: 33). Stensen's manual dexterity must have been superb and, one might speculate, inherited from the father who was a goldsmith and thus had to rely on the fine movement of the fingers. Stensen's dissection skills, therefore, enabled him access to the structures "hidden" to other researchers. The writer in the local Parisian journal remarked "he makes most of what he presents so vivid that one is obliged to be convinced, and one may only wonder that it has escaped the notice of all earlier anatomist" (Cutler, 2003: 33). Stensen also manipulated animal tissue to get a better insight into their structure. While studying the cardiovascular system, for example, he boiled an animal heart. This enabled him to easily peel of the other layers of the heart wall and have a better insight into the structure of myocardium and led to a supposition that the "the heart is simply a muscle" (Tubbs et al., 2012). This he further corroborated by a comparison with a skeletal muscle. In addition, he was keen to observe the tissues he studied under the microscope.

In addition to dissection, Stensen carried out a variety of experiments (Kardel \& Maquet). He, for example, placed a ligature on the descending aorta of an animal to observe that this resulted in the paralysis of a lower limb. The removal of the ligature restored the function. This experiment is now known as Stensen's experiment.

Stensen made a number of important discoveries in anatomy (Kardel\& Maquet). Early in his career he wrote an authoritative discourse on the anatomy of the glands and lymphatics of the head (see below). He discovered incisive canals of the hard palate, which now bear his name - Stensen's foramina, as do the vorticose veins of the eye - Stensen's veins. He further gave impressive contributions to the understanding of structure and function of organs of the cardiovascular, nervous, muscular and reproductive systems. He not only demonstrated that the heart was made of muscle tissue, but that it worked as a muscular pump rather than a heating mechanism which increased the temperature and thus expelled the blood, as many (most notably Descartes) maintained. He was first to describe the congenital malformation of the heart now known as the Tetralogy of Fallot (Tubbs et al., 2012). Stensen also hypothesised that muscles produce movement through contraction rather than by expanding muscle volume (Kardel, 1990, 1994, 2008; Andrault, 2010) He successfully argued against many unsubstantiated claims about the functions of the nervous system, including the claim of the ancients that the ventricles were the "seat of the soul" (Perrini et al.; Tubbs et al., 2011; Parent, 2013). Stensen discovered the follicles of the ovary before his friend and colleague Reinier de Graaf (Kardel \& Maquet). However, he lost the primacy of the discovery as he only published his account about it in 1675 , three years after de Graaf. Although some of Stensen's findings, in their original form, are not acceptable by the standards of modern science, in the seventeenth century they represented significant advancements in the knowledge of anatomy.

The brilliant career of an anatomist, however, started with Stensen's discovery and description of the parotid duct, an accomplishment for which he is best known today (Riva \& Testa Riva, 1996).

\section{DISCOVERY OF THE PAROTID DUCT}

The discovery of the parotid duct happened during Stensen's brief stay in Amsterdam in the early 1660s, while he was working under Blaes (Riva \& Testa Riva; Kardel \& Maquet). The existence of the duct was later confirmed and its anatomy further elucidated through the research carried out while Stensen was at Leiden. The discovery, as described by Stensen himself in his communication to his Danish mentor Bartholin, was to a large extent serendipitous. Stensen bought a sheep's head with an intention to dissect the animal's brain. However, he decided to expand the dissection to the other parts of the head. Stensen (in Kardel \& Maquet, 2013: 354) described the drama, unpredictability and excitement of a scientific discovery:

A year ago, as I had been received by Blaes as my host, seeing a good opportunity of having anatomical subjects in that series of lectures which he finished in the third week of my arrival, I asked the very famous gentleman to allow me to 
dissect with my own hand what I would provide for myself. Having obtained that, I was so lucky that, at the first opportunity, on April 7, when I was dissecting alone in the small study, I found in a sheep's head a duct which nobody had described as far as I know. Having removed all the common wrappings, I considered dissecting the brain when casually I decided to examine first the vessels passing through the mouth. Thus, exploring to this end with a probe pushed in the paths of the arteries and veins, I observed that its tip no longer was retained inside the straits of the tunics but roamed in a large cavity. While pushing the metal, I soon heard the teeth resound. Amazed by the novelty of the thing, I called my host to hear his opinion. He at first accused me of having forced my way, and then he resorted to the all too frequent plays of Nature and finally checked in Wharton.

Blaes, therefore, according to Stensen's account, suggested that the structure was an artefact created by Stensen's careless cutting or that it was a variation and sought further clarification in the works of the leading authority on the matter, English anatomist Thomas Wharton. Stensen, however, decided to further investigate the region himself and continued to dissect it. He next dissected the head of a dog, only to confirm his assumption that he discovered a structure - a duct of a salivary gland - which had not been described previously. He told his close friend and colleague Jacob Henrik Paulli that he "had discovered a small salivary duct and added a description of it" (Stensen in Kardel \& Maquet, 2013: 354).

Stensen soon moved to Leiden to resume his medical studies and research in anatomy. He continued his study of the parotid duct and related structures with a new vigour, capitalising on the world class research infrastructure and expertise of the Leiden academics. That the structure was a duct of the parotid gland was confirmed through dissection of human cadavers carried out at Leiden. In his 1661 study De Glandulis Oris \& Novis Inde Prodeuntibus Salivae Vasis (On the Glands of the Mouth and the New Salivary Ducts Proceeding from Them) Stensen described the position and relation of the parotid duct in some animals and humans and provided detailed illustrations. He noted:

If we consider its [parotid duct's] straight course in man by which it passes between the gland and the middle of the buccinator muscle, it seems to be like a strong cord which, originating laterally from the centre of the buccinator muscle, crawls through the bone of the cheeks and ends in a small and thin muscle directly opposite the cheek... (Stensen in Kardel \& Maquet, 2013: 367).

Stensen's mentors Sylvius and van Horne, both renowned scholars, acknowledge the discovery and its importance. Van Horne introduced an eponym for the structure
- ductus Stenonianus (Scherz in Kardel \& Maquet, 2013).

The acknowledgement and prise for Stensen, however, were not received well by Blaes, who made a public claim that Stensen stole his work on parotid duct. That led to an open controversy and heated debate over the primacy in this discovery. Blaes launched a campaign against Stensen, contacted their colleagues and painted a picture of Stensen as a plagiarist, enforced by offensive personal remarks. Stensen responded vigorously but his approach to this debate was different. He started an intensive research project in which he systematically investigated not just parotid, but all the glands in the head. Indeed, without being personal or emotional, he showed that Blaes was incorrect and that, in fact, his knowledge of the duct and gland were incomplete and confused while his dissertation on glands simply copied Wharton's work. Stensen's several publications on the glands that followed showed his mastery of the subject (Riva \& Testa Riva; Kardel \& Maquet). Not only had he correctly described the parotid duct and its relations, he also provided several other seminal insights. He clearly distinguished between what was known as conglomerate glands (to which Stensen referred as "glands in the proper sense") and conglobate glands (lymph nodes). He noted that the term "parotid" was ascribed to two different structures - the gland that produces saliva and secretes it through a duct into the oral cavity, as well as the closely associated lymph nodes (conglobates). Stensen described the anatomy and position of other glands including submandibular and minor salivary glands such as palatine and buccal. He also discussed the function of these glands, claiming that they produce saliva by filtering arterial blood.

By the-mid 1663, however, the polemic between Blaes and Stensen seemed to come to its end rather abruptly. Blaes, probably as a result of Stensen's competent rebuttal, did not provide any reply and stopped challenging his younger colleague. Furthermore, although he did not spare accusatory and offensive words in his attack on Stensen, Blaes would in the future often refer to Stensen and cite his work. Indeed, as Scherz (in Kardel \& Maquet, 2013: 66) noted, in Blaes' most famous work the Anatome Animalium, Stensen was "among the most frequently quoted authors".

Chance played a role in the discovery of the parotid gland as it did in many other similar instances in the history of science. Indeed, many distinguished scientists emphasised the role of luck in science. In the words of Sydney Brenner, "you do need luck in science. Everyone needs luck. Luck helps" (Brenner et al., 2001). Luck, however, is of little importance if one cannot take the advantage of the opportunity. Stensen, it would appear, quickly recognised the importance of the parotid duct, its structure and function, unlike Blaes who seemed to fail to contextualise the structure and was later 
unable to position it properly within the oral cavity.

Stensen's delayed publication on some anatomical discoveries, as already mentioned, cost him the recognition of being the discoverer. Interestingly, two other anatomists seemed to be close to publishing a description of parotid duct before Stensen. Italian anatomist Giulio Casseri presented the opening of the parotid duct in one of the illustration of his 1600 De Vocis Auditusque Organis, but failed to describe it (Riva et al., 2001). English anatomist Walter Needham discovered it in 1655 , but only described it twelve years later in his Disquisitio Anatomica de Formatio Foetu (Scherz in Kardel\& Maquet, 2013). It was, therefore, probably due to chance that Stensen was in a position to be the first to report the presence of the parotid duct. There is, indeed, much in James Watson's advice to leave nothing to chance when it comes to reporting a discovery. He noted simply "Immediately write up big discoveries" (Watson, 2007: 153).

Chance related to parotid duct discovery played a significant role in Stensen's career in yet another way. While in Leiden, Stensen contemplated a career in mathematics (Scherz in Kardel \& Maquet, 2013). However, his engagement in the dispute with Blaes, and his decision to carry out a comprehensive research of the glands of the head, turned him back to anatomy with an increased enthusiasm and the ambition to seriously tackle mathematics never materialised.

In presenting his discovery to the scientific community, Stensen found himself in an exceptionally difficult and threatening position for a young scientist, being accused of plagiarism and stealing the discovery from an elder academic. The approach to discussion on primacy was diametrically different between the two scientists. Blaes engaged in a propaganda war against his young opponent and developed a public relations (PR) strategy to advertise his primacy and undermine his opponent, through a network of friends within the scientific community. However, as John Waller (2002: 13) noted, "during the verification stage, the prognosis for bad idea supported by good PR is extremely poor". Blaes' idea was bad in the sense that he could not express it properly, as he did not have full comprehension and reliable data about the anatomical structure that he claimed to have had discovered. Blaes' strategy was successful only for a brief period of time at the beginning of the dispute. Stensen's approach was more demanding but at the same time scientifically more sound, proving to be more profitable in the long run. He focused all his energy to more research, following his initial discovery. This resulted not just in further elucidation of the anatomy of the parotid duct, but also led him to more insights in the anatomy of the oral cavity and associated glands in general. The results of this research effort, therefore, overshadowed the original subject of the debate and surpassed it in scope and depth. During the dispute young Stensen showed remarkable maturity, not compromising his integrity or abandoning his high academic standards, thus managing to fight off the serious accusations against him.

Interestingly, Stensen did not think of the discovery of the parotid duct it as one of his major accomplishments, especially when compared to the results of some of his later research in anatomy. However, this discovery launched Stensen's career in science and helped him establish himself as one of the leading anatomists of the day.

\section{CONCLUSION}

Niels Stensen remains one of the most notable scientists in the history of anatomy. His method based on dissection and experiment enabled him to make significant contribution to the understanding of structure and function of human body. Like many successful scientists he was able to make the most of the rather serendipitous discovery of the parotid duct early in his career, soon expanding his research focus into new areas. Scholarly stature and personal integrity enabled young Stensen to overcome the difficulties he encountered when forced to enter into a disputation over the primacy in the discovery of the parotid duct. The high standards that characterised him as a scientist also typified Stensen in the later stages of his inspiring life which he dedicated to spirituality and religious leadership. Niels Stensen was a heroic figure in more than one way, an exemplary scholar not only in his own time but for the generations to come.

STRKALJ, G. Niels Stensen y el descubrimiento del conducto parotídeo. Int. J. Morphol., 31(4):1491-1497, 2013.

RESUMEN: Niels Stensen fue un renombrado científico danés, obispo y teólogo católico. A principios de su carrera Stensen se dedicó a la anatomía, disciplina en la cual logró muchas contribuciones importantes. Su método de anatomía se fundamentaba en observaciones sistemáticas basadas en disecciones de cadáveres humanos y de animales ejecutadas meticulosamente, así como los experimentos con animales. Su primer descubrimiento importante en el campo de la anatomía, que constituye el tema principal de este trabajo, fue el descubrimiento del conducto parotídeo. El descubrimiento le trajo el reconocimiento y fama a Stensen, pero sólo después de una polémica en la que se le acusaba de plagio por su mentor Gerard Blaes. A pesar de haber estado en una etapa temprana de su carrera, Stensen se hizo cargo de la acusación con maestría, produciendo una mayor investigación que lo confirma como el descubridor del conducto parotídeo.

PALABRAS CLAVE: Niels Stensen; Historia de la anatomía; Conducto patotídeo; Descubrimiento científico. 


\section{REFERENCES}

Andrault, R. Mathematizing anatomy: the myology of Stensen (1667). Early Sci. Med., 15:505-36, 2010.

Brenner, S.; Wolpert, L.; Friedberg, E. C. \& Lawrence, E. Sydney Brenner: A Life in Science. London, BioMed Central, 2001.

Crivellato, E. \& Ribatti, D. Mondino de' Luzzi and his Anothomia: A milestone in the development of modern anatomy. Clin. Anat., 19(7):581-97, 2006.

Cutler, A. The Seashell on the Mountaintop: A Story of Science, Sainthood and the Humble Genius Who Discovered a New History of the Earth. London, Heinmann, 2003.

Field, E. J. \& Harrison, R. J. Anatomical Terms: Their Origin and Derivation. Cambridge, W. Heffer and Sons Ltd., 1947.

Finger, S. Origins of Neuroscience: A History of Explorations into Brain Function. New York, Oxford University Press, 1994.

Joffe, S. N. Andreas Vesalius: The Making, the Madman, and the Myth. Bloomington, Persona Publishing, 2009.

Kardel, T. Niels Stensen's geometrical theory of muscle contraction (1667): A reappraisal. J. Biomech., 23(10):953-65, 1990.

Kardel, T. Stensen's myology in historical perspective. T. Am. Philos. Soc., 84:1-59, 1994.

Kardel, T. Nicolaus Steno's new myology (1667): Rather than muscle, the motor fibre should be called animal's organ of movement. Nuncius, 23(1):37-64, 2008.

Kardel, T. \& Maquet, P. NicolausSteno: Biography and Original Papers of a 17th Century Scientist. Heidelberg, Springer, 2013.

Kermit, H. Niels Stensen, 1638-1686: The Scientist Who was Beatified. Leominster, Gracewing, 2003.

Kevorkian, J. The Story of Dissection. New York, Philosophical Library, 1959.

Kidd, M. \& Modlin, I. M. The Luminati of Leiden: From Bontius to Boerhaave. World. J. Surg., 23(12):1307-14, 1999.

Maar, V. Nicolai Stenonis Opera Philosophica. Copenhagen, Tryde, 1910.

O'Malley, C. D. Andreas Vesalius of Brussels, 1514-1564. Berkeley, University of California Press, 1964.

Osler, W. Man and books. Can. Med. Assoc. J., 12:67-71, 1913.

Parent, A. Niels Stensen: a 17th century scientist with a modern view of brain organization. Can. J. Neurol. Sci., 40(4):482-92, 2013.

Perrini, P.; Lanzino, G. \& Parenti, G. F. Niels Stensen (1638-1686): Scientist, neuroanatomist, and saint. Neurosurgery, 67(1):3-9, 2010.
Persaud, T. V. N. Early History of Human Anatomy: From Antiquity to the Beginning of the Modern Era. Springfield, Charles C. Thomas, 1984.

Persaud, T. V. N. A History of Anatomy: The Post-Vesalian Era. Springfield, Charles C. Thomas, 1997.

Riva, A.; Orrù, B.; Pirino, A. \& Riva, F. T. Iulius Casserius (15521616): The self-made anatomist of Padua's Golden Age. Anat. Rec., 265(4):168-75, 2001.

Riva, A. \& Testa Riva, F. Niels Stensen (Niccolò Stenone) and his first scientific offspring: the salivary glands. Eur. J. Morphol., 34(3):137-41, 1996.

Scherz, G. Niels Stensen: Eine Biographie. Leipzig, St. Benno-Verlag, 1987.

Schumacher, G. E. Theatrum Anatomicum in history and today. Int. J. Morphol., 25(1):15-32, 2007.

Singer, C. A Short History of Anatomy and Physiology from Greeks to Harvey. New York, Dover, 1957.

Strkalj, G. \& Chorn, D. Herophilus of Chalcedon and the practice of dissection in Hellenistic Alexandria. S. Afr. Med. J., 98(2):86-9, 2008.

Tubbs, R. S.; Gianaris, N.; Shoja, M. M.; Loukas, M. \& Cohen Gadol, A. A. The heart is simply a muscle" and first description of the tetralogy of "Fallot". Early contributions to cardiac anatomy and pathology by bishop and anatomist Niels Stensen (1638-1686). Int. J. Cardiol., 154(3):312-5, 2012.

Tubbs, R. S.; Mortazavi, M. M.; Shoja, M. M.; Loukas, M. \& CohenGadol, A. A. The bishop and anatomist Niels Stensen (1638-1686) and his contributions to our early understanding of the brain. Childs Nerv. Syst., 27(1):1-6, 2011.

Von Staden, H. Herophilus: The Art of Medicine in Alexandria. Cambridge, Cambridge University Press, 1989.

Waller, J. Fabulous Science: Fact and Fiction in the History of Scientific Discovery. Oxford, Oxford University Press, 2002.

Watson, J. D. Avoid Boring People and Other Lessons from a Life in Science. Oxford, Oxford University Press, 2007.

\section{Correspodence to: \\ Prof. Goran Strkalj \\ Faculty of Science \\ C5C Building \\ Macquarie University \\ Sydney, NSW 2109 \\ AUSTRALIA}

E-mail: goran.strkalj@mq.edu.au

Received: 13-08-2013

Accepted: 02-11-2013 